\title{
Proceeding
}

8th INSHS International Christmas Sport Scientific Conference, 5-7 December 2013. International Network of Sport and Health

Science. Szombathely, Hungary

\section{The use of information technology in non-formal education of handball coaches}

\author{
TOMÁŠ AUGUSTÝN , VLADIMÍR JƯVA \\ Faculty of Sports Studies, Masaryk University Brno, the Czech Republic.
}

\begin{abstract}
Augustýn, T. \& Jůva, V. (2014). The use of information technology in non-formal education of handball coaches. J. Hum. Sport Exerc., 9(Proc1), pp.S335-S340. Information and Communication Technology (ICT) plays an increasingly important role in the gradation of the coaching profession. Our empirical research targets this area, specifically questions the use of ICT in non-formal education and informal learning of coaches of handball. The empirical research method was to analyze the specific forms and methods of use of information technology (video channels, social networks, electronic databases, websites, computer programs, smart phones, etc.) in non-formal education and informal learning of coaches. The research had two phases. In the first phase, a questionnaire was designed which was then distributed to coaches from various sports. Data were collected from 186 coaches. After the quantitative evaluation of the survey, case studies (interviews) with three selected coaches of handball were completed. The results showed that ICT systems were commonly used both in personal life and their coaching. In connection with the system activity, predominately using one-way communication, especially the study - methodic guidelines. Two-way communication, such as Internet e-learning courses, forums, webinars, etc. were used significantly less. Coaches do not use ICT in their direct coaching too often during training or a match, while particularly at the top level usually work on a computer with video. Key words: INFORMATION AND COMMUNICATION TECHNOLOGY (ICT), METHODIC - STUDY GUIDELINES, ONE-WAY COMMUNICATION, TWO-WAY COMMUNICATION.
\end{abstract}

Corresponding author. Faculty of Sports Studies, Masaryk University Brno, the Czech Republic.

E-mail: august@mail.muni.cz

8th INSHS International Christmas Sport Scientific Conference, 5-7 December 2013. International Network of Sport and Health Science. Szombathely, Hungary.

JOURNAL OF HUMAN SPORT \& EXERCISE ISSN 1988-5202

(C) Faculty of Education. University of Alicante

doi:10.14198/jhse.2014.9.Proc1.17 


\section{INTRODUCTION}

The development of the coaching profession has recently increased its attention (Jansa \& Dovalil 2009; Sekot 2006; Trudel \& Gilbert 2006) and some results of empirical research have been published in this area (Jansa \& Kovář 2008; Lavallee 2006).

Our research focuses on the question of the use of Information and Communication Technologies (ICTs) in non-formal education and informal learning among coaches of handball.

The objective of this empirical research was to analyse specific forms and methods of the use of information technologies (websites, CD and DVD media, video channels, social network, electronic databases, computer programmes, smart phones, etc.) in non-formal education and informal learning among handball coaches.

To the most frequently used sources belong materials of the union/federation websites, to the least used belong the paid sources, E-learning, webinars and video conferencing. This certainly corresponds to the offer, which is wide on the club/federation websites, on the contrary there is a minimum amount of paid sources and webinars or video conferencing, these are still not too much offered form of education.

We will present a detailed analysis comparing the use of information technologies among coaches of handball and other sports. For now, we do not register a wide use of newer technologies such as tablets and smart phones, handball coaches compared to other coaches use computers, tablets and smart phones at all monitored activities less.

\section{METHODOLOGY}

The research had two phases, a quantitative and a qualitative one.

In the period from January to July 2013 a questionnaire survey was carried out. We designed our own questionnaire which was used and distributed electronically through authorized persons by email or delivered personally in a printed form. The aim of the survey was to obtain an overview of selected aspects of the use of information technology in non-formal education and informal learning among coaches of different sports.

\section{RESULTS}

Representation of respondents in particular sport sectors is shown in Figure 1

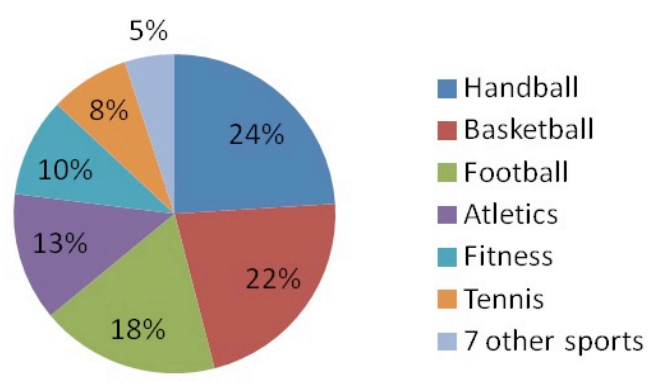

Figure 1. Representation of respondents in particular sport sectors 
Overall, there were 186 returned and completed questionnaires, the observed characteristics of the study sample are shown in the Figure 1. In the final section we will compare coaches of handball and other sport sectors, therefore the data of both samples are quantified separately. In both groups more coaches are men (handball $80 \%$, other $69 \%$ ). The strongest age group in both groups is $31-45$ years (handball $48 \%$, other $51 \%$ ). The highest level of education achieved by coaches in both groups is secondary education (handball $62 \%$, other $51 \%$ ). $7 \%$ of handball coaches against $21 \%$ of other coaches reached higher education with sports focus university degree. Most respondents are B licensed (second class) - handball $48 \%$, other $46 \%$, just $12 \%$ of handball coaches and $16 \%$ of other sports coaches reached the highest license. The most handball coaches act as volunteers $(59 \%)$, while the others mostly act as semiprofessionals (37\%). Coaches of handball mostly coach exclusively male groups (48\%), other coaches do mixed groups of males and females (44\%). A more detailed overview is given in Table 1.

We are fully aware of the relatively low number of survey respondents, that is why we do not want to generalize the results of this survey to the entire group of coaches of handball and other sports in the Czech Republic and all the results are presented in percentage terms.

Table 1. Characteristics of the study sample (indicated in percentage, $N=186$ )

\begin{tabular}{lllllll}
\hline & \multicolumn{2}{l}{ Computer } & Tablet & \multicolumn{2}{l}{ Mobile phone } \\
\hline & Handb. & Other & Handb. & Other & Handb. & Other \\
\hline In preparation for a training unit & 70 & 81 & 5 & 16 & 7 & 13 \\
During a training unit & 9 & 13 & 0 & 8 & 16 & 15 \\
When evaluating a training unit & 38 & 14 & 2 & 12 & 2 & 3 \\
In preparation for a match & 47 & 54 & 0 & 9 & 9 & 10 \\
During a match & 14 & 15 & 0 & 6 & 2 & 1 \\
Evaluating matches / races & 51 & 58 & 2 & 7 & 7 & 3 \\
\hline
\end{tabular}

In the second phase, three selected coaches were interviewed. Selection of trainers was deliberate, three experienced coaching personalities of handball were chosen, this was the most represented sector among respondents. Dušan Poloz - 2012/2013 Czech champion with a women's team DHK Baník Most, head coach of women's representation in Slovakia, Jaroslav Hudeček - men's national coach of the Czech Republic, Jana Hajžmanová - longtime coach of youth teams HC Baník Karvina (they became champions of the Czech Republic several times). The purpose of these interviews was to clarify opinions and attitudes on selected topics from the first phase.

Table 2. The use of different sources (indicated in percentage)

\begin{tabular}{lllll}
\hline & Handball & \multicolumn{2}{l}{ Others } \\
\hline & Yes & No & Yes & No \\
\hline Methodical materials on the the Czech Federation website & 91 & 5 & 73 & 21 \\
Methodical materials on foreign union websites & 49 & 36 & 48 & 46 \\
Methodical materials on european federation website & 33 & 44 & 38 & 56 \\
Methodical materials on world federation website & 21 & 46 & 27 & 65 \\
Video conference or webinar & 12 & 55 & 10 & 77 \\
E-learning courses & 7 & 58 & 14 & 78 \\
Online paid sources & 5 & 58 & 6 & 76 \\
\hline
\end{tabular}


In the survey, coaches commented on the use of different information sources through ICT. They most often use methodological materials on the websites of National Federations. Handball coaches use these more $(91 \%)$ compared to other sports coaches $(73 \%)$. The second most commonly used are websites of other national associations (49\% handball coaches, $48 \%$ other coaches) and then European sports federations websites (33\% of handball coaches, $38 \%$ of other sports coaches). Modern forms of education and gaining information such as video conferencing and webinars, E-learning courses and online paid sources are used very little. A more detailed overview is given in Table 2.

Handball coaches compared to other coaches use internet sources in foreign languages more than coaches of other sports. On the contrary handball coaches use internet sources in the English language less (42\%) compared to coaches of other sports (56\%) and also sources on a CD and a DVD are used less by handball coaches (41\% vs. $62 \%$ of other coaches). However handball coaches use sources in German language more than others. $39 \%$ of handball coaches use internet sources compared to $18 \%$ of other sports coaches, sources on a CD and a DVD use $39 \%$ of them compared to $25 \%$ of other sports coaches. A more detailed overview is given in Table 3.

Table 3. The use of foreign sources (indicated in percentage)

\begin{tabular}{|c|c|c|c|c|c|c|c|c|c|c|c|c|}
\hline & \multicolumn{2}{|l|}{ English } & \multicolumn{2}{|l|}{ Slovak } & \multicolumn{2}{|l|}{ German } & \multicolumn{2}{|l|}{ Polish } & \multicolumn{2}{|c|}{$\begin{array}{l}\text { Other } \\
\text { languages }\end{array}$} & \multicolumn{2}{|l|}{ Sum } \\
\hline & Handb. & Other & Handb. & Other & Handb. & Other & Handb. & Other & Handb. & Other & Handb. & Other \\
\hline $\begin{array}{ll}\text { CD } & \text { and } \\
\text { DVD } & \end{array}$ & 41 & 62 & 28 & 35 & 39 & 25 & 9 & 1 & 9 & 6 & 126 & 129 \\
\hline $\begin{array}{l}\text { Internet } \\
\text { sources }\end{array}$ & 42 & 56 & 40 & 31 & 39 & 18 & 14 & 1 & 4 & 6 & 139 & 112 \\
\hline
\end{tabular}

Table 4. The use of ICT in the work of coaches (indicated in percentage)

\begin{tabular}{lllllll}
\hline & \multicolumn{2}{l}{ Computer } & Tablet & \multicolumn{2}{l}{ Mobile phone } \\
\hline & Handb. & Other & Handb. & Other & Handb. & Other \\
\hline In preparation for a training unit & 70 & 81 & 5 & 16 & 7 & 13 \\
During a training unit & 9 & 13 & 0 & 8 & 16 & 15 \\
When evaluating a training unit & 38 & 14 & 2 & 12 & 2 & 3 \\
In preparation for a match & 47 & 54 & 0 & 9 & 9 & 10 \\
During a match & 14 & 15 & 0 & 6 & 2 & 1 \\
Evaluating matches / races & 51 & 58 & 2 & 7 & 7 & 3 \\
\hline
\end{tabular}

Handball coaches express greater satisfaction with a range of methodological materials available on the internet and on a CD and a DVD. The offer of methodological materials on a CD and a DVD in Czech language is positively evaluated by $59 \%$ of handball coaches and by $32 \%$ negatively, compared to other sports coaches - only $46 \%$ of a positive evaluation and $39 \%$ of a negative one. Foreign sources are evaluated in a positive way by $60 \%$ of handball coaches, in a negative way by $5 \%$ of them, $43 \%$ of other sports coaches evaluate positively and $32 \%$ negatively.

A computer is the most commonly used means of ICT in everyday practice by both groups of coaches. It is most used in a preparation for a training unit (used by $70 \%$ of handball coaches and by $81 \%$ of other coaches), when evaluating a match/race (51\% of handball coaches, $58 \%$ of other coaches) and when preparing for a match ( $47 \%$ of handball coaches, $54 \%$ of other coaches). A computer is used the least during a training unit ( $9 \%$ of handball coaches, $13 \%$ of other coaches). The big difference is in the use of 
computers when evaluating a training unit - $38 \%$ of handball coaches use it compared to $14 \%$ of coaches of other sports. Compared with computers, tablets are very little used and mobile phones even less. A more detailed overview is given in Table 4.

\section{DISCUSSION}

The results of the survey showed the selected characteristics of the use of ICT in non-formal education and informal learning among handball coaches in the Czech Republic compared to other sports coaches. To the most frequently used sources belong materials of the union/federation websites, to the least used belong the paid sources, E-learning, webinars and video conferencing. This certainly corresponds to the offer, which is wide on the club/federation websites, on the contrary there is a minimum amount of paid sources and webinars or video conferencing, these are still not too much offered form of education. Three coaches who were interviewed, state various uses of information sources but all emphasize the strong influence of other coaches (especially club coaches or national teams coaches) for their own professional development.

A large majority $(70 \%)$ of handball coaches use a computer in preparation for a training unit. Preparing for the training unit was widely discussed in interviews with three selected coaches and all of them do a written preparation for a training unit and usually use a variety of materials, including methodological CDs and DVDs or internet sources. It can be assumed that most of the $70 \%$ above - mentioned coaches will act likewise. The use of computers directly during the game (stated by $14 \%$ of respondents) belongs to the interesting data. None of the three selected coaches mentions the use of computers directly in a match.

The use of tablets, which are easier to handle and could also be used in training units, is not widespread yet. One of the interviewed coaches states this for example when he spoke about the coach in Norway, who showed a training exercise on a tablet to his players during a training unit, just before its own implementation. He also states other examples of the sophistication in the use of ICT in Norway (eg. training diary guidance by broader national selected players in intranet, services for video editing of a match, an extensive range of methodological materials, etc.). It can also be expected a progressive use of mobile phones with a large computing power and plenty of features to use such as a camera, the ability to work with video but apparently there is a lack of appropriate applications to enable their wider use.

\section{CONCLUSIONS}

The results of the empirical survey showed the selected characteristics of the use of information technologies by sports coaches. Considering the extent of the research sample (186 respondents), the presented results cannot be generalized to the wide coaching population.

The research results show that there prevails satisfaction with available materials in the Czech language and in other languages with handball coaches. They most often work with English, Slovak and German from all foreign languages. With the exception of German they work with foreign language sources less than coaches of other sports. $91 \%$ of them commonly use methodological materials on the Czech Handball Federation website which is on the contrary more than with other sports.

A computer is the most often used means of ICT by handball coaches. However they use it less than other coaches in all the monitored activities, with the exception of the evaluation of training units. The use of tablets and mobile phones is still low so far. 
The article was funded by specific research project on FSpS MU No. 512120 - "The use of information technology in non-formal learning of sports coaches".

\section{REFERENCES}

1. Jansa, P., Kocourek, J. \& Kovář, K. (2009). Základy pedagogiky sportu. In P. Jansa \& J. Dovalil (Eds.). Sportovni príprava: vybrané kinantropologické obory $k$ podpoře aktivního životního stylu (pp.38-71). Praha: Q-art.

2. Jansa, P. \& Kovářr, K. (2008). Názory a postoje trenérů ve vybraných sportech. In Současný sportovní trénink (pp.317-321). Praha: UK.

3. Lavallee, D. (2006). Career Awareness, Career Planning, and Career Transition Needs Among Sports Coaches. Journal of Career Development, 33(1), pp.66-79.

4. Sekot, A. (2006). K sociálním aspektům profesní pozice trenéra. In Sport jako sociálně-kulturní fenomén (pp.13-30). Brno: Masarykova univerzita.

5. Trudel, P. \& Gilbert, W. (2006). Coaching and Coach Education. In D. Kirk, D. Macdonald \& M. O'Sullivan (Eds.) The Handbook of Physical Education (pp.516-539). London: SAGE Publications. 